\title{
PENGARUH HARGA DAN FREE WI-FI TERHADAP KEPUTUSAN PEMBELIAN PRODUK PADA ANGKRINGAN DI KECAMATAN KARAS KABUPATEN MAGETAN
}

\author{
Kizal Ula Ananata $\mathrm{r}$ auzi $1^{*}$ \\ ${ }^{1}$ Universitas YGKJ Madiun \\ *Korespondensi: rizalmanajmen@gmail.com
}

\begin{abstract}
This study aims to analyze the influences of price and Free Wi-Fi on consumer purchasing decisions at angkringan In Karas Magetan district The specific objective of this esearch is to know how the influence of Price Variables on Consumer Purchasing Decisions On Angkringan in Karas Magetan district. To provide know the influence of Variable Free Wi-Fi to Decision Purchase consumer On Angkringan in District Karas Magetan District. The research method used in this research with quantitative approach. Population in this research is all consumer of Angkringan in district of Karas Magetan Regency. samples taken are consumers angkringan for 3 months in Karas district, Magetan regency. Based on the formula Rao Purba, the number of samples taken as many as 97 respondents. Data collection techniques were conducted by using questionnaires and interviews, while data processing used was editing, coding and tabulation. The results of the study are. Free WIFI significantly effect to Consumer Purchase Decision on Angkringan in district of Karas Magetan Regency.
\end{abstract}

Keywords: Price, free Wifi, purchase decision

\begin{abstract}
ABSTRAK
Penelitian ini bertujuan untuk menganalisis pengaruh harga dan Free Wi-Fi terhadap keputusan pembelian konsumen di angkringan di kecamatan Karas Kabupaten MagetanTujuan spesifik dari penelitian ini adalah untuk mengetahui bagaimana pengaruh Variabel harga terhadap keputusan pembelian konsumen Pada Angkringan di Kabupaten Karas Magetan. Untuk mengetahui pengaruh Variabel Free Wi-Fi terhadap Keputusan Pembelian Konsumen Pada Angkringan di kecamatan Karas kabupaten Magetan.Metode penelitian yang digunakan dalam penelitian ini adalah dengan pendekatan kuantitatif. Populasi dalam penelitian ini adalah seluruh konsumen Angkringan di Kecamatan Karas kabupaten Magetan. Sampel yang diambil adalah konsumen angkringan selama 3 bulan di Kecamatan Karas, Kabupaten Magetan. Berdasarkan rumusan Rao Purba, jumlah sampel yang diambil sebanyak 97 responden. Teknik pengumpulan data dilakukan dengan menggunakan kuesioner dan wawancara, sedangkan pengolahan data yang digunakan adalah editing, coding dan tabulasi. Hasil penelitian ini adalah. Free WIFI berpengaruh signifikan terhadap Keputusan Pembelian Konsumen Angkringan di Kabupaten Karas Magetan
\end{abstract}

Kata kunci: Harga, Free Wifi , keputusan pembelian

\section{PENDAHULUAN}

Era globalisasi yang didukung oleh pesatnya perkembangan ilmu pengetahuan dan teknololgi khususnya teknologi tepat guna, telah menghadapkan dunia pada era revolusi industri atau yang lebih dikenal sebagai era informasi, Perkembangan teknologi komunikasi dan informasi yang pesat, dapat ditandai dengan ditemukannya internet. Internet telah memberi suatu solusi yang sangat praktis bagi masyarakat dalam mencari informasi dan juga terjalinnya komunikasi untuk memenuhi kebutuhan. 
Tingginya minat masyarakat terhadap akses internet yang lebih cepat membuat WiFi menjadi suatu hal yang penting di kalangan masyarakat modern untuk menunjang kebutuhan berinternet. Sehingga merubah sedikit fenomena keadaan masyarakat. Salah satu tempat yang paling banyak dipilih oleh masyarakat yang ada di kabupaten Magetan dalam akses internet saat ini adalah angkringan yang menyediakan layanan Wi-Fi. Saat ini sudah semakin banyak outlet atau lokasi tertentu yang menyediakan layanan Wi-Fi. Sehingga pengguna dapat dengan mudah melakukan akses internet tanpa kabel.

Eksistensi angkringan ber-Wifi ini menjadi potret baru dalam kurun waktu 2 tahun terakhir di kabupaten Magetan. Angkringan ber-Wifi ini lebih diminati oleh para pengunjung yang mengakses internet. Angkringan yang dulu hanya tempat cari makan sekarang angkringan berfungsi ganda: angkringan -net (tempat jajan dan tempat internet). Sehingga keberadaan angkringan menjadi sebuah perhatian apakah ketentuan harga masih menjadi perhatian untuk memjadi rujukan pembelian atau WI-Fi menjadi salah satu pilihan pembelian.

Untuk dapat memperoleh informasi yang lebih jelas dan disertai bukti ilmiah mengenai seberapa besar pengaruh harga dan free Wi-Fi terhadap keputusan konsumen membeli di angkringan kabupaten Magetan maka dilakukan penelitian dengan rumusan permasalahan penelitian sebagai berikut:

1) Apakah terdapat pengaruh yang signifikan Variabel harga terhadap Keputusan pembelian Produk pada Angkringan di kecamatan Karas Kabupaten Magetan?

2) Apakah terdapat pengaruh yang signifikan Variabel Free Wi-Fi terhadap Keputusan Pembelian Produk pada Angkringan di kecamatan Karas Kabupaten Magetan?

Selanjutnya penelitian ini bertujuan untuk mengetahui pengaruh persepsi harga, persepsi

Free WI-FI terhadap keputusan pembelian produk pada angkringan di Kecamatan Karas Kabupaten Magetan, maka diperoleh tujuan dari penelitian ini adalah

1) Untuk memberikan bukti empiris Pengaruh Variabel Harga terhadap Keputusan Pembelian produk pada Angkringan di kecamatan Karas Kabupaten Magetan.

2) Untuk memberikan bukti empiris tentang Pengaruh Variabel Free Wi-Fi terhadap Keputusan Pembelian produk pada Angkringan di kecamatan Karas Kabupaten Magetan.

\section{TINJAUAN PUSTAKA}

\subsection{Keputusan pembelian}

Nugroho (2002: 2) menyatakan bahwa keputusan membeli adalah merupakan suatu proses aktivitas masing-masing individu yang dilakukan dalam rangka mengevaluasi, mendapatkan, penggunaan, serta mengatur barang dan jasa. Menurut Kotler (2009:184) keputusan pembelian konsumen adalah keputusan membeli barang dan jasa. Sedangkan menurut Tjiptono (2008:19) mengemukanan bahwa keputusan pembelian konsumen adalah memilihn barang satu dengan 
lainnya. Menurut Husain Umar (2000: 51) kepuasan dibagi dua macam yaitu kepuasan fungsional dan kepuasan psikologika. Kepuasan fungsional merupakan kepuasan yang diperoleh dari fungsi suatu produk yang dimanfaatkan sedangkan kepuasan psikologikal merupakan kepuasan yang diperoleh dari atribut yang bersifat tidak berwujud dari produk.

Menurut Harmani (2008:41) Keputusan Pembelian diukur oleh 3 indikator antara lain: a). Keputusan terhadap produk yang berkualitas, b). Keputusan terhadap harga yang diberikan, c). Keputusan terhadap pelayanan yang diberikan. Dalam keputusan pembelian terdapat lima peran yang terjadi dalam keputusan membeli : a. Pemrakarsa (initiator) b. Pemberi pengaruh (influencer) c. Pengambil keputusan (decider) d. Pembeli (buyer) e. Pemakai (user) (Simamora, 2001 : 15). Sehingga dari keputusan pembelihan yang ada mempengaruhi minat konsumen untuk membeli sebuah produk yang ada. Keputusan pembelian merupakan kegiatan yang dilakukan konsumen dimana mereka membeli suatu produk oleh penjual.

\subsection{Harga}

Harga merupakan unsur bauran pemasaran yang sifatnya fleksibel dimana setiap saat dapat berubah menurut waktu dan tempatnya. Menurut Kotler dan Keller (2009:67) harga adalah salah satu elemen bauran pemasaran yang menghasilkan pendapatan, elemen lain menghasilkan biaya. Harga merupakan elemen termudah dalam program pemasaran untuk disesuaikan, fitur produk, saluran, dan bahkan komunikasi membutuhkan banyak waktu. Pendapat lain menurut Tjiptono (2008:151) harga merupakan satu-satunya unsur bauran pemasaran yang memberikan pemasukan atau pendapatan bagi perusahaan.

Menurut Kotler dan Amstrong (2012:52), didalam variabel harga ada beberapa unsur kegiatan utama harga yang meliputi tingkatan harga, diskon, potongan harga, dan periode pembayaran. Menurut Kotler dan Amstrong (2008:278) ada 4 (empat) indikator yang mencirikan harga yaitu : keterjangkauan harga, kesesuaian harga dengan kualitas produk, daya saing harga, kesesuaian harga dengan manfaat. Dengan demikian penilaian terhadap harga suatu produk dikatakan mahal, murah atau biasa saja dari setiap individu tidaklah harus sama karena tergantung dari persepsi individu yang dilatarbelakangi oleh lingkungan kehidupan dan kondisi individu.

Harga memiliki peranan utama dalam proses pengambilan keputusan para pembeli Tjiptono, (2008), yaitu : Peranan alokasi harga, yaitu fungsi harga dalam membantu para pembeli untuk memutuskan cara memperoleh manfaat atau utilitas tertinggi yang diharapkan 4 berdasarkan daya belinya, Peranan informasi dari harga, yaitu fungsi harga dalam membidik konsumen mengenai faktor-faktor produk, seperti kualitas.

\subsection{Wi-Fi}

Wi-Fi adalah nama lain yang diberikan untuk produk Wireless Local Area Network (WLAN) adalah jaringan komputer yang menggunakan gelombang radio sebagai media transmisi 
data. Wi-Fi atau Wireless Fidelity adalah satu standar Wireless Networking tanpa kabel, hanya dengan komponen yang sesuai dapat terkoneksi ke jaringan (Priyambodo, 2005: 1).

Sebuah hotspot pada umumnya dilengkapi dengan password yang bisa meminimalisasi siapa saja yang bisa menggunakan fasilitas stersebut. orang-orang diseluruh dunia memahami manfaat konektivitas jaringan untuk memeriksa e-mail, menjelajah internet, dan mengakses aplikasi korporat (Geier, 2005: 26). Ini sering digunakan oleh pengguna rumahan, restoran, swalayan, café dan hotel. Wi-Fi dapat di akses dengan peralatan Wi-Fi certified Radio seperti komputer, laptop, PDA atau Cellphone.

\subsection{Penelitian Terdahulu}

Penelitian terdahulu sangat penting sebagai dasar pijakan dalam rangka penyusunan penelitian ini. Kegunaanya untuk mengetahui hasil yang telah dilakukan oleh peneliti terdahulu.

Tabel.1 Penelitian Terdahulu.

\begin{tabular}{|c|c|c|c|}
\hline \\
\hline Penulis & Judul & Variabel & Hasil \\
\hline Ichwanul Akbar (2011) & $\begin{array}{l}\text { Pengaruh harga dan } \\
\text { promosi terhadap } \\
\text { keputusan pembelian } \\
\text { konsumen pada } \\
\text { produk minuman } \\
\text { Coca-cola }\end{array}$ & $\begin{array}{l}\text { Harga, Promosi, } \\
\text { keputusan } \\
\text { pembelian }\end{array}$ & $\begin{array}{l}\text { Harga dan promosi berpengaruh } \\
\text { positif terhadap keputusan } \\
\text { pembelian. }\end{array}$ \\
\hline $\begin{array}{l}\text { Rino Sardanto Sigit } \\
\text { Ratnanto } \\
(2016)\end{array}$ & $\begin{array}{l}\text { Pengaruh Persepsi } \\
\text { Konsumen Terhadap } \\
\text { Keputusan Pada } \\
\text { Angkringan Kota } \\
\text { Kediri }\end{array}$ & $\begin{array}{l}\text { Pengaruh Persepsi } \\
\text { Konsumen } \\
\text { Keputusan }\end{array}$ & $\begin{array}{l}\text { variabel persepsi konsumen } \\
\text { terhadap keragaman produk, harga } \\
\text { dan kualitas pelayanan dan } \\
\text { pengaruh positif yang signifikan } \\
\text { terhadap keputusan pembelian }\end{array}$ \\
\hline $\begin{array}{l}\text { Miswar Muhammad ( } \\
\text { 2017) }\end{array}$ & $\begin{array}{l}\text { Pengaruh Wi Fi } \\
\text { (Wireless Fidelity) } \\
\text { Terhadap Pengunjung } \\
\text { Warung Kopi Di Kota } \\
\text { Banda Aceh }\end{array}$ & $\begin{array}{l}\text { Wifi dan } \\
\text { pengunjung }\end{array}$ & $\begin{array}{l}\text { Wifi mempengaruhi minat } \\
\text { pengunjung warung kopi. }\end{array}$ \\
\hline
\end{tabular}

\section{5 kerangka pemikiran}

Kerangka berfikir dalam suatu penelitian perlu dikemukakan apabila dalam penelitian tersebut berkenaan dua variabel atau lebih. Apabila penelitian hanya membahas sebuah variabel atau lebih secara mandiri, maka yang dilakukan peneliti disamping mengemukakan deskripsi teoritis untuk masing-masing variabel, juga argumentasi terhadap variasi besaran variabel yang diteliti (Sapto Haryoko, 1999, dalam Sugiyono, 2010).

Dalam penelitian ini kerangka pemikiran dapat digambarkan dibawah ini:

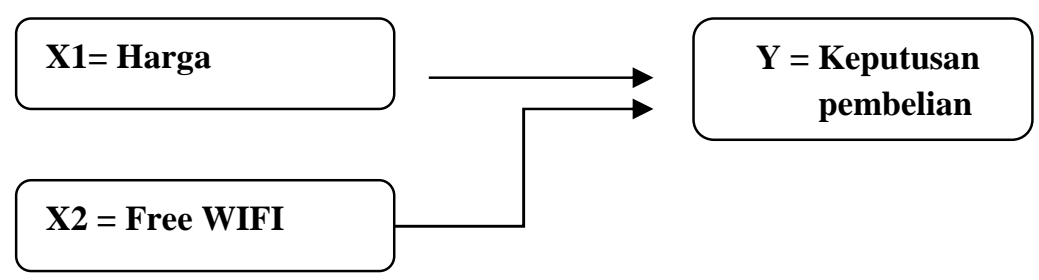

Gambar.1 Kerangka Pemikiran 
Berdasarkan kerangka pemikiran di atas, maka hipotesis penelitian yang diajukan adalah sebagai berikut:

H1 : Diduga terdapat pengaruh yang signifikan Variabel Harga terhadap Keputusan Pembelian Konsumen Pada Angkringan di kecamatan Karas Kabupaten Magetan.

H2 : Diduga terdapat pengaruh yang signifikan Variabel Free Wi-Fi terhadap Keputusan Pembelian konsumen pada Angkringan di kecamatan Karas Kabupaten Magetan.

\section{METODE}

penelitian ini dilakukan di wilayah kecamatan Karas Kabupaten Magetan, waktu pelaksanaan tiga bulan terhitung Agustus sampai Oktober 2017. Menurut Sugiyono (2010:115) populasi adalah wilayah generalisasi yang terdiri atas obyek/subyek yang mempunyai kualitas dan karakteristik tertentu yang ditetapkan oleh peneliti untuk dipelajari dan kemudian ditarik kesimpulannya. Populasi dalam penelitian ini adalah seluruh konsumen Angkringan di kecamatan Karas Kabupaten Magetan.

Dalam penelitian ini sampel yang diambil yaitu konsumen angkringan selama 3 bulan di kecamatan Karas Kabupaten Magetan. Karena jumlah populasi dari penelitian ini tidak teridentifikasi, maka dalam menentukan sampel penelitian dari populasi tersebut dapat didasarkan pada rumus Rao Purba (1996:34), jumlah sampel minimal ditentukan sebagai berikut:

$$
\begin{aligned}
& n=\frac{z^{2}}{4(\text { moe })^{2}} \\
& n=\frac{(1.96)^{2}}{4(0,1)^{2}} \\
& n=96,6 \text { dibulatkan } 97
\end{aligned}
$$

Dimana:

$$
\begin{aligned}
& n \quad=\text { Jumlah sampel } \\
& z \quad=\text { Tingkat distribusi normal pada taraf signifikan } 5 \%(1,96) \\
& \text { mue }=\text { Margin of Error Max, adalah tingkat kesalahan maksimal pengambilan }
\end{aligned}
$$

sampel yang masih dapat di toleransi sebesar 10\%

Berdasarkan rumus diatas, maka jumlah sampel yang diambil yaitu sebanyak 97 orang responden..

Teknik pengambilan sampel dalam penelitian ini yaitu menggunakan Non Probability Sampling yang mana merupakan teknik pengambilan sampel yang tidak memberi peluang/kesempatan sama bagi setiap unsur atau anggota populasi untuk dipilih menjadi sampel (Sugiyono, 2010:120). Oleh kerena itu Metode pengambilan sampel dalam penelitian ini 
menggunakan sampling insidental (accidental sampling) yaitu teknik pengambilan sampel berdasarkan kebetulan, siapa saja yang secara kebetulan/insidental bertemu dengan peneliti.

\subsection{Definisi Operasional}

Definisi operasional variabel merupakan beberapa variabel yang menjadi model penelitian yang bisa diamati. Definisi operasional penelitian ini meliputi:

\subsection{Harga(X1)}

Kotler dan Amstrong (2008:278) ada 4 (empat) indikator yang mencirikan harga yaitu : keterjangkauan harga, kesesuaian harga dengan kualitas produk, daya saing harga, kesesuaian harga dengan manfaat. Harga merukan salah satu pertimbangan ketika konsumen akan membeli sebuah produk.

\subsection{Wifi(X2)}

Indikator variabel Wifi adalah 1.Kecepatan akses,2.Jangkauan area dan 3. Kemudahan penggunaan Kecepatan akses (wifi) dalam mengakses internet sangat penting untuk menggambarkan kemampuan dari suatu layanan (wifi) yang meliputi kecepatan upload dan download. Jangkauan area sinyal hotspot menggambarkan seberapa luas area atau lokasi yang terjangkau oleh jaringan hotspot (wifi). Sedangkan Kemudahan penggunaan menggambarkan sejauh mana pengguna dimudahkan dalam mengakses layanan hotspot (wifi).yaitu kemudahan dalam hal mencari atau mendapatkan sinyal hotspot, login hotspot (wifi).

\subsection{Keputusan pembelian(Y)}

Indikator variabel Keputusan pembelian adalah 1. Kemantapan pada sebuah produk, 2. Rekomendasi kepada orang lain, 3. Pembelian ulang. Kemantapan pada sebuah produk bagaimana konsumen merasakan suka dan yakin terhadap produk yang akan dibelinya, rekomendasi orang lain merupakan saran yanag diberikan orang lain untuk membeli sebuah produk yang akan dibeli. Sedangkan pembelian ulang ketika konsumen merasakan puas terhadap produk yang dibelinya,

\subsection{Pengumpulan Data}

Teknik pengumpulan data yang dilakukan dengan cara menyusun daftar pertanyaan secara terperinci yang ada hubungannya dengan penulisan penelitian untuk kemudian dibagikan kepada sejumlah responden yang telah ditetapkan. Kuesioner yang diberikan bersifat pertanyaan terbuka dan tertutup.

Untuk pertanyaan tertutup peneliti menggunakan skala Likert sebagai skala pengukurnya di mana responden dapat memberikan penilaian dengan skala 1-5 yaitu sangat setuju, setuju, ragu-ragu, tidak setuju, sangat tidak setuju. Instrumen penelitian yang digunakan yaitu berbentuk checklist. Instrumen penelitian adalah suatu alat yang digunakan untuk mengukur fenomena alam maupun sosial yang diamati (Sugiyono, 2010:146). Sedangkan untuk pertanyaan terbuka responden dapat memberikan tanggapan yang diungkapkan dengan tulisan. 
Menurut Ghozali (2013:52) uji validitas yang digunakan untuk mengukur sah atau valid tidaknya suatu koesioner. Suatu koesioner dinyatakan valid jika pernyataan pada kuesioner mampu untuk mengungkapkan sesuatu yang akan diukur oleh kuesioner tersebut. Untuk menguji apakah masing-masing indikator valid atau tidak dapat melihat tampilan output Cronbach Alpha pada kolom Correlated Item - Total Correlated. Dengan membandingkan nilai Correlated Item Total Correlated dengan hasil perhitungan $r$ tabel. Jika $r$ hitung lebih besar dari $r$ tabel dan nilai positif maka butir atau pertanyaan atau indikator tersebut dinyatakan valid.

Menurut Wijaya (2010:111) pengujian reliabilitas adalah berkaitan dengan masalah adanya kepercayaan terhadap instrumen. Suatu instrumen dapat memiliki tingkat kepercayaan yang tinggi (konsisten) jika hasil pengujian dari pengujian instrumen tersebut menunjukkan hasil yang tetap. Reliabilitas < 0,6 adalah kurang baik atau kurang reliabel.

Uji normalitas bertujuan untuk menguji apakah dalam model regresi, variabel pengganggu atau residual memiliki distribusi normal. Seperti diketahui bahwa uji $t$ dan uji $F$ mengasumsikan bahwa nilai residual mengikuti distribusi normal (Ghozali, 2013: 160). Dalam penelitian ini menggunakan metode Kolmogorov-Smirnov (K-S). Uji K-S dengan dilakukan dengan membuat hipotesis : H0 : Data residul berdistribusi normal, Ha: Data residul tidak berdistribusi normal. Jika nilai hasil uji Kolmogorov-Smirnov (K-S) > taraf signifikansi 0,05 maka data berdistribusi normal.

Untuk mendeteksi adanya ditribusi normal, maka bisa melihat penyebaran data (titik) pada sumbu diagonal dan grafik, dengan dasar pengambilan keputusan sebagai berikut :

1) Jika data menyebar di sekitar garis diagonal dan mengikuti arah garis diagonal, maka model regresi memenuhi asumsi normalitas.

2) Jika data menyebar jauh dari garis diagonal dan/atau tidak mengikuti arah garis diagonal, maka model regresi tidak memenuhi asumsi normalitas. (Santoso, $2001: 214$ ).

Uji heteroskedastisitas bertujuan untuk menguji apakah modal regresi terjadi kesamaan varians dari residual satu pengamatan ke pengamatan lain. Model regresi yang baik adalah yang tidak terjadi heteroskedastisitas. Salah satunya melihat Grafik Plot antara nilai prediksi variabel terikat (dependent) yaitu ZPRED dengan residualnya SRESID. Deteksi ada tidaknya heteroskedastisitas dapat dilakukan dengan melihat ada tidaknya pola tertentu pada grafik scatter plot antara SRESID dan ZPRED dimana sumbu Y adalah Y yang telah diprediksi, dan sumbu X adalah residual (Y prediksi ${ }^{-}$Y sesungguhnya) yang telah di-studentized (Ghozali, 2013: 139). Dasar pengambilan keputusan uji tersebut yaitu jika ada titik-titik yang membentuk pola tertentu yang teratur seperti bergelombang, melebar kemudian menyempit, maka mengindikasikan adanya heteroskedastisitas. Jika tidak terdapat pola tertentu yang jelas, serta titik-titik menyebar diatas dandibawah angka nol pada sumbu Y maka mengindikasikan tidak terjadi heteroskedastisitas. 
Uji multikolinearitas bertujuan apakah model regresi ditemukan adanya korelasi antara variabel bebas (independent). Model regresi yang baik adalah tidak terjadi korelasi diantara variabel independent (Ghozali, 2013: 105). Pendeteksian terhadap multikolinearitas dapat dilakukan dengan melihat nilai Variance Inflating Faktor (VIF) dari hasil analisis regresi.

Besaran nilai Variance Inflating Faktor (VIF): VIF = 1/Tolerance

1) Jika nilai VIF> 10 atau jika nilai tolerance $<0,1$ maka ada multikolinearitas dalam model regresi.

2) Jika nilai VIF < 10 atau jika nilai tolerance $>0,1$ maka tidak ada multikolinearitas dalam model regresi.

\section{PEMBAHASAN}

\subsection{Pengujian Normalitas}

Untuk mendeteksi adanya ditribusi normal, maka bisa melihat penyebaran data (titik) pada sumbu diagonal dan grafik, dengan dasar pengambilan keputusan sebagai berikut :

1) Jika data menyebar di sekitar garis diagonal dan mengikuti arah garis diagonal, maka model regresi memenuhi asumsi normalitas.

2) Jika data menyebar jauh dari garis diagonal dan/atau tidak mengikuti arah garis diagonal, maka model regresi tidak memenuhi asumsi normalitas. (Santoso, $2001: 214$ ).

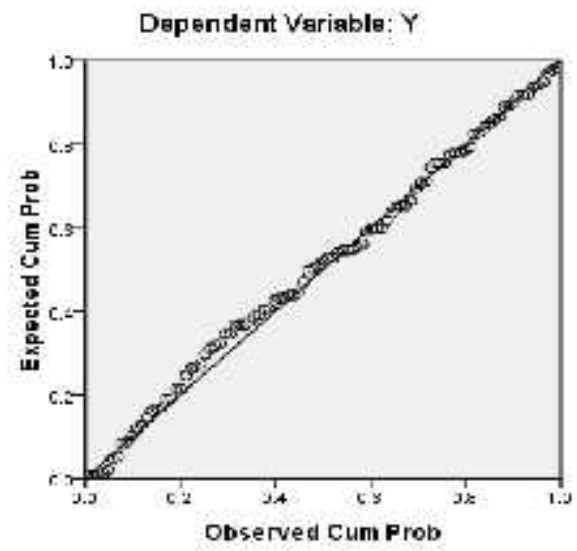

Gambar. 2 Uji Normalitas

Dari Gambar 2 tersebut diketahui bahwa data menyebar di sekitar garis diagonal dan mengikuti arah garis diagonal, maka model regresi memenuhi asumsi normalitas.

\subsection{Uji Multikolinieritas}

Uji multikolinieritas adalah pengujian pada model regresi, dimana pengujian ini bertujuan untuk menguji apakah ditemukan adanya korelasi antara variabel bebas (independen), jika terjadi korelasi maka dinamakan multikolinieritas. Sedangkan untuk mengetahui gejala tersebut dapat dideteksi dari besarnya nilai VIP (Variance Inflation Factor) melalui program SPSS. Nilai umum yang digunakan untuk menunjukkan adanya multikolinieritas adalah nilai 
toleransi $<0,10$ atau sama dengan nilai VIF $>10$. Dan sebaliknya apabila VIF $<10$ maka tidak terjadi multikolinieritas.

Tabel .2 Uji Multikolinieritas.

\begin{tabular}{lccll}
\hline Variabel & Tolerance & Vif & & Keterangan \\
\hline Harga & 0.458 & 2.185 & bebas multikolinieritas & \\
\hline free wifi & 0.458 & 2.185 & bebas multikolinieritas & \\
\hline
\end{tabular}

Dari hasil perhitungan menunjukkan bahwa semua variabel bebas yang memiliki tolerance lebih dari $0,1(>0,1)$ dan semua variabel bebas memiliki nilai VIF kurang dari 10. Jadi dapat disimpulkan bahwa tidak ada gejala multikolinieritas dalam model regresi.

\subsection{Uji Heteroskedastisitas}

Untuk mendeteksi adanya heteroskedastisitas adalah dengan melihat grafik scatterplot di mana sumbu $\mathrm{X}$ adalah $\mathrm{Y}$ yang telah diprediksi dan sumbu $\mathrm{X}$ adalah residual (Y prediksi - $\mathrm{Y}$ sesungguhnya) yang telah di studentized. Yang menjadi dasar pengambilan keputusan dalam menentukan sebuah penelitian terkena heteroskedastisitas atau tidak adalah:

1) Jika terdapat data pola tertentu, seperti titik-titik yang ada membentuk suatu pola tertentu yang teratur (bergelombang, melebar kemudian menyempit), maka telah terjadi heteroskedastisitas.

2) Jika tidak terdapat pola yang jelas, serta titik-titik menyebar di atas dan di bawah angka 0 pada sumbu Y, maka tidak terjadi heteroskedastisitas.

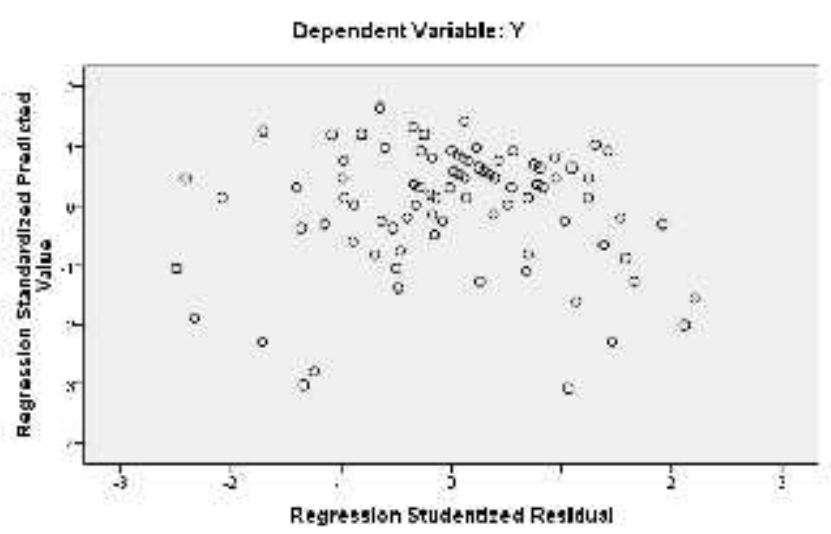

Gambar 3 Uji Heteroskedastisitas

Dari Gambar 3 tersebut diketahui bahwa tidak terdapat pola yang jelas, serta titik-titik menyebar di atas dan di bawah angka 0 pada sumbu Y, maka tidak terjadi heterokedastisitas.

\subsection{Pengujian Hipotesis dengan Analisis Regresi}


Uji hipotesis ini digunakan untuk menguji hipotesis yang di ungkapkan oleh peneliti mengenai penelitian ini dapat diterima atau ditolak. Uji hipotesis dalam penelitian ini adalah uji $\mathrm{t}$ yang di uji dengan bantuan software SPSS versi 17 for windows.

\section{Tabel 2. Coefficient}

\begin{tabular}{|c|c|c|c|c|c|c|c|c|}
\hline \multicolumn{9}{|c|}{ Coefficients $^{\mathrm{a}}$} \\
\hline & & $\begin{array}{r}\text { Unstar } \\
\text { Coef }\end{array}$ & $\begin{array}{l}\text { ardized } \\
\text { cients }\end{array}$ & $\begin{array}{l}\text { Standardized } \\
\text { Coefficients }\end{array}$ & & & Collinearity & atistics \\
\hline \multicolumn{2}{|l|}{ Model } & $\mathrm{B}$ & Std. Error & Beta & $\mathrm{T}$ & Sig. & Tolerance & VIF \\
\hline \multirow[t]{3}{*}{1} & $\begin{array}{l}\text { (Consta } \\
\text { nt) }\end{array}$ & 1.157 & .321 & & 3.604 & .001 & & \\
\hline & $\mathrm{X} 1$ & .176 & .117 & .172 & 1.500 & .137 & .458 & 2.185 \\
\hline & $\mathrm{X} 2$ & .533 & .116 & .524 & 4.584 & .000 & .458 & 2.185 \\
\hline
\end{tabular}

a. Dependent Variable: $\mathrm{Y}$

Pengujian hipotesis dalam penelitian ini menggunakan uji t (pengaruh secara individual). Pengujian ini dimaksudkan untuk mengetahui signifikansi dari pengaruh variabel independen terhadap variabel dependen secara individual. Pengujian nilai t dilakukan dengan dua sisi yang digunakan untuk menguji hipotesis. Hasil pengujian diperoleh dari test signifikansi dengan program SPSS Hasil pengujian t dapat dilihat pada Tabel 3 berikut:

Tabel 3 Hasil Uji t

\begin{tabular}{lrrrc}
\hline \multicolumn{1}{c}{ Variabel } & \multicolumn{1}{c}{$\boldsymbol{t}_{\text {hiturg }}$} & $\boldsymbol{t}_{\text {tnbel }}$ & Sig. & Keterangan \\
\hline Harga & 1.500 & 1,985 & 0,137 & $H_{0}$ ditolak \\
Free Wifi & 4.584 & 1,985 & 0,000 & $H_{0}$ diterima \\
\hline
\end{tabular}

Keterangan $*)=\mathrm{t}_{\text {tabel }}$ pada taraf signifikansi $5 \%$

\subsection{Hipotesis Yang Pertama $\left(\mathrm{H}_{1}\right)$}

Hasil uji t dapat menunjukkan bahwa variabel Harga memiliki nilai $\mathrm{t}_{\text {hitung }}=1.500$ dengan nilai sifnifikasi $=0,137$, sedangkan $t_{\text {tabel }}$ pada taraf signifikansi $5 \%$ adalah $=1,985$. Dikarenakan $\left.\mathrm{t}_{\text {hitung }}<\mathrm{t}_{\text {tabel }} 1.500<1,985\right)$ dengan nilai signifikasi $>0,05$, maka $\mathrm{H}_{2}$ ditolak. Artinya harga secara statistik tidak memberikan pengaruh terhadap Keputusan Pembelian Konsumen pada Angkringan di kecamatan Karas Kabupaten Magetan. Hasil penelitian ini tidak berhasil mendukung hipotesis $\mathrm{H}_{1}$ bahwa Variabel Harga berpengaruh signifikan terhadap Keputusan Pembelian konsumen pada Angkringan di kecamatan Karas Kabupaten Magetan

Harga di angkringan pada dasarnya lebih murah dibandingkan warung konvensional yang harus mengeluarkan biaya lebih banyak untuk pemasaran, sewa tempat/ruko, bayar listrik, bayar pajak dan lain - lain yang dibebankan kepada konsumen, namun demikian angkringan bisa 
menentukan harga lebih tinggii sesuai dengan keinginna penjual hal tersebut terbukti ada angkringan ynag menjual kopi seharga 5000 rupiah dua kali harga dari umumnya tempat jajan.

Oleh karena itu angkringan yang ada di kecamatan Karas kabupaten Magetan harga tidak menjadikan sebagai pertimbangan masyarakat untuk melakukan pembelian pada angkringan di kecamatan Karas Kabupaten magetan hal ini tidak sesuai dengan penelitian Ichwanul Akbar (2011) dan Rino Sardanto Sigit Ratnanto (2016) bahwa harga perpengaruh positif terhadap pembelian.

\subsection{Hipotesis Yang kedua $\left(\mathrm{H}_{2}\right.$}

Hasil uji t dapat menunjukkan bahwa variabel Free WIFI memiliki nilai $\mathrm{t}_{\text {hitung }}=4.583$ dengan nilai sifnifikasi $=0,00$, sedangkan $t_{\text {tabel }}$ pada taraf signifikansi $5 \%$ adalah $=1,985$. Dikarenakan $\mathrm{t}_{\text {hitung }}>\mathrm{t}_{\text {tabel }}(4,483>1,985)$ dengan nilai signifikasi $<0,05$, maka $_{2}$ diterima. Artinya variabel Free WIFI secara statistik memberikan pengaruh terhadap Keputusan Pembelian Konsumen Pada Angkringan di kecamatan Karas Kabupaten Magetan. Hasil penelitian ini berhasil mendukung hipotesis $\mathrm{H}_{2}$ bahwa Variabel Free Wi-Fi berpengaruh signifikan terhadap Keputusan Pembelian konsumen pada Angkringan di kecamatan Karas Kabupaten Magetan.

Keberadaan Wifi menjadikan salah satu pertimbangan konsumen untuk membeli jajan pada angkringan, hal ini di karenakan selain membeli jajan konsumen juga mencari wifi untuk mencari informasi ataupun membrowsing di internet, baik mengerjakan tugas kuliah maupun sekedar mencari berita ataupun bermain game. Para pemilik angkringan berlomba memberikan akses wifi berkecpatan lumayan tinggi sebagai salah satu pemasaran angkringannya. Hal ini memdukungpenelitian dari Miswar Muhammad bahwa Free WiFi berpengaruh terhadap pengunjung warung kopi

\subsection{Koefisien Determinasi $\left(\mathrm{R}^{2}\right)$}

Koefisien determinasi (Adjusted $\boldsymbol{K}^{2}$ ) bertujuan untuk mengetahui seberapa besar kemampuan variabel independen menjelaskan variabel dependen. Dalam output SPSS, koefisien determinasi terletak pada tabel Model Summary ${ }^{\circ}$ dan tertulis Adjusted R Square. Berikut tabel 4.

Tabel 4. Koefisien Determinasi

\begin{tabular}{lllllllllll}
\hline & & & \multicolumn{9}{c}{ Change Statistics } \\
Model & $\mathrm{R}$ & $\begin{array}{l}\text { R } \\
\text { Square }\end{array}$ & $\begin{array}{l}\text { Rdjusted } \\
\text { R Square }\end{array}$ & $\begin{array}{l}\text { Std. Error } \\
\text { of } \\
\text { the }\end{array}$ & $\begin{array}{l}\text { R Square } \\
\text { Change }\end{array}$ & $\begin{array}{l}\mathrm{F} \\
\text { Change }\end{array}$ & df1 & df2 & $\begin{array}{l}\text { Sig. F } \\
\text { Change }\end{array}$ \\
\hline 1 & .661 & .437 & .425 & .36243 & .437 & 36.572 & 2 & 94 & .000 \\
\hline
\end{tabular}


Dari pengujian yang telah dilaksanakan menghasilkan nilai koefisien determinasi $\mathrm{R}^{2}$ sebesar 0,437, Hal ini menunjukkan bahwa sekitar 43,7\% variasi dari Keputusan Pembelian Konsumen Pada Angkringan di kecamatan Karas Kabupaten Magetan dapat

dijelaskan oleh variabel Harga dan Free WiFi. Sedangkan sekitar 56,3\% dapat dijelaskan oleh variabel lain di luar model.

\section{KESIMPULAN}

Berdasarkan hasil penelitian yang diperoleh maka dapat disimpulkan harga tidak memberikan pengaruh terhadap keputusan pembelian konsumen pada angkringan di kecamatan Karas Kabupaten Magetan. sehingga ketika harga naik tidak terlalu mengurangi pembelian oleh konsumen. Sedangkan Variabel Free WIFI memberikan pengaruh terhadap keputusan pembelian konsumen pada angkringan di kecamatan Karas Kabupaten Magetan. sehinga dengan adanya free Wifi dapat meningkatkan penjualan produk pada angkringan.

\section{SARAN DAN UCAPAN TERIMAKASIH}

Bedasarkan pada hasil kesimpulan diatas, maka saran yang diberikan bahwa faktor dari 2 dimensi variabel Harga dan Free WiFi terhadap keputusan pembelian perlu dikembangkan lagi hal-hal yang mempengaruhi faktor-faktor keputusan pembelian. Variabel harga dan variabel Free Wifi memberikan pengaruh sebesar $43,7 \%$ dari keputusan pembelian, oleh karena itu untuk peneliti selanjutkanya bisa menambah variabel independen yang mempengaruhi keputusan pembelian. Hal tersebut bisa lokasi menjadikan sebuat pilihan ataupun refrensi dari teman juga merupakan pengaruh pilihan pembelian pada angkringan yang belum ada dalam penelitian ini 


\section{DAFTAR PUSTAKA}

Akbar, Ichwanul (2011) Pengaruh harga dan promosi terhadap keputusan pembelian konsumen pada produk minuman Coca-cola Volume 1, Nomor 3, November 2015 Jurnal Ilmiah Manajemen dan Bisnis.

Fandy Tjiptono. 2008. Strategi Pemasaran. Edisi 3. Yogyakarta: Andi Offset

Geiser, J. 2005. Wireless Networks First-Step. Yogyakarta: ANDI

Ghozali,Imam .2013. Aplikasi Analisis Multivariat dengan Program SPSS. Semarang: Badan Penerbit.

Husein Umar, 2004. Metode Penelitian Untuk Skripsi dan Tesis Bisnis, Jakarta: Raja Grafindo Persada

Ichwanul, Akbar.2011.Pengaruh Harga dan Promosi Terhadap Keputusan Pembelian Konsumen pada Produk Minuman Coca-cola. Universitas Mercubuana, Jakarta.

Kotler, A. 2008. Prinsip-Prnsip Pemasaran Jilid 1 dan 2, Edisi 12. Jakarta: Erlangga.

---------, 2012. Principles Of Marketing 14 edition.

---------, 2009. Marketing Management, 13 th edition, Prentice Hall. New Jersey.

Kotler, Philip. dan Gary Armstrong. 2008. Prinsip prinsip Pemasaran. Edisi ke 12 Jilid 1. Jakarta: Erlangga.

Miswar Muhammad .2017.Pengaruh Wi Fi (Wireless Fidelity) Terhadap Pengunjung Warung Kopi Di Kota Banda Aceh Universitas Islam Negeri Ar-Raniry Darussalam

Nugroho, Adi, 2002. Perilaku Konsumen. Jakarta: Studio Press.

Priyambodo, TK. 2005. Jaringan Wi-Fi, Teori \& Implementasi. Yogyakarta: ANDI.

Rao, Purba. 1996. Measuring Customer Perceptions ThroughFactur Analysis, The Asian Manager, February, March.

Santoso, Singgih. 2001. Buku Latihan SPSS Statistik Parametrik. Elex Media Komputindo, Jakarta.

Sardanto, Rinodan Sigit Ratnanto 2016 Pengaruh Persepsi Konsumen Terhadap Keputusan Pada Angkringan Kota Kediri VOL. 3 NO. 1 Juli 2016 Jurnal Benefit

Simamora, Bilson. 2001. Panduan Riset perilaku Konsumen. Jakarta : PT. Gramedia Pustaka Utama

Sugiyono. 2010. Metodologi Penelitian Bisnis Cetakan Kelimabelas. Bandung : Alfabeta.

Sugiyono . 2010. metode penelitian pendidikan pendekatan kuantitatif, kualitatif dan R \& D, Bandung : Cv. Alfa Beta

Winarno,Edy; Zaki, Ali, dan Community, SmitDev, 2010. Tip Perawatan dan Optimasi Perangkat Keras Komputer. Jakarta: Elex Media Komputindo

Wijaya, T. 2010. Cepat Menguasai SPSS 19. Yogyakarta: Cahaya Atma

Yusup, Muhammad 2011.Analisis pengaruh promosi, harga, Kualitas produk dan layanan purna jual Terhadap keputusan pembelian sepeda Motor Honda Universitas Diponegoro Semarang. 